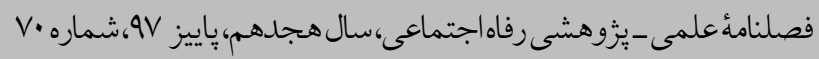

Social Welfare Quarterly, Vol 18, Fall 2018, No 70

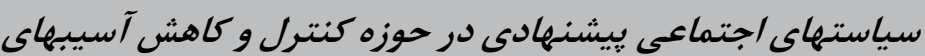
اجتماعسى در/يران درون

\title{
Suggested Social Policies to Control Social Harms in
}

\section{Iran}

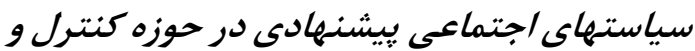 كاهش آسيبهاى /جتماعى درى ايران دروان}

مقدمه: يكى /ز وظايف دولتها اتخاذ سياستهاى مناسب براى /رتقاء

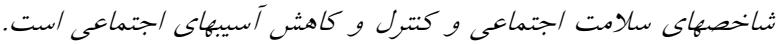

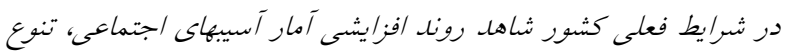

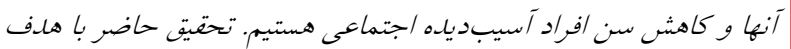

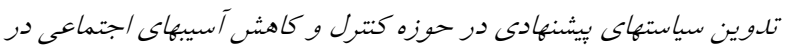

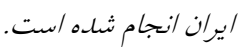

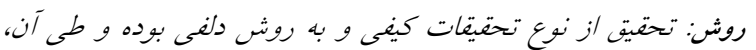

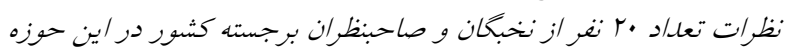
استخراج كرديل.

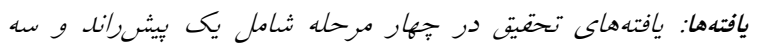

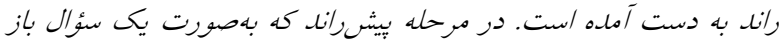

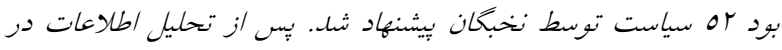

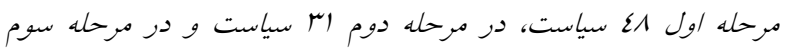

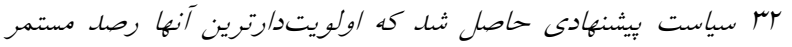

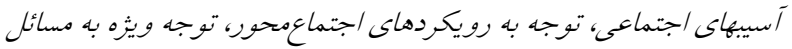

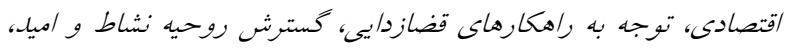

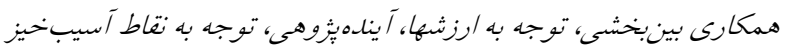

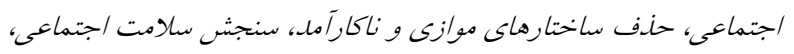

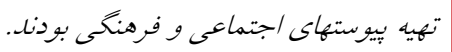

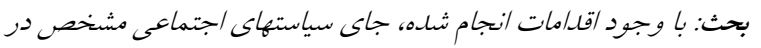

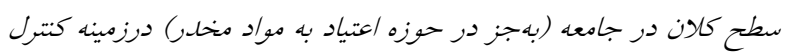

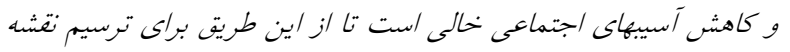

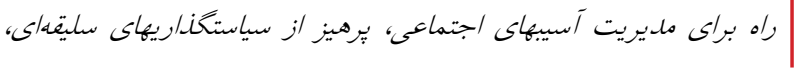

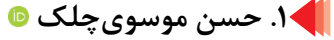

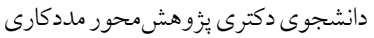

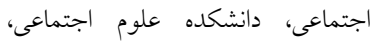 دانشكاه علامه طباطبايى، تهران، ايران إنماع،

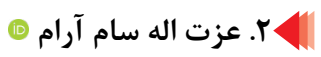

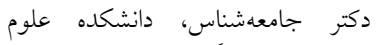

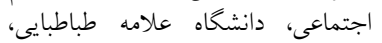 تهران، ايران (نويسنده مسئول) <e_samaram@yahoo.com>}

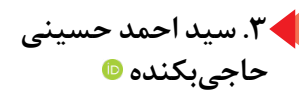

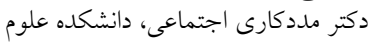

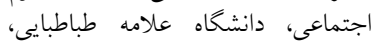
تهران، ايران 
Social Welfare Quarterly, Vol 18, Fall 2018, No 70

بهرهيرى /ز همه ظرفيتها در بخش دولتى و غيردولتى، هماهنكيهاى بينبخشى و فرابخشى، مليريت بهينه منابع،

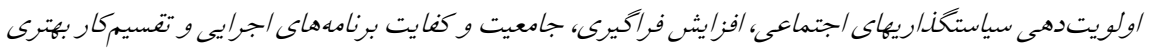
بين دستخاههاى مرتبط /قدام شود.

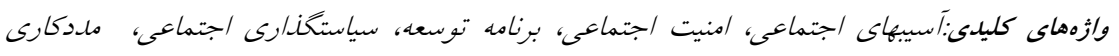
اجتماعى وأن

تاريخ دريافت:

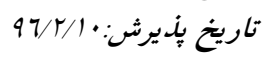


سياستهاى اجتماعى يشئهادى در حوزه كترل و كاهش آسيبهاى اجتماعى در ايران

Suggested Social Policies to Control Social Harms in Iran

\section{Suggested Social Policies to Control Social Harms in Iran}

1- Hassan Mousavi Chelak 무 PhD student in social work, research-based, Social Science Faculty, allameh tabataba'i university, Tehran, Iran

\section{2- Ezzatolla Samaram (D)} Ph.D in Sociology (Social Sciences), Social Science Faculty, allameh tabataba'i university, Tehran, Iran, (corresponding author) e_samaram@yahoo.com

\section{3- Seyed Ahmad Hoseini} Hajibekandeh (D) Ph.D in Social science, Social Science Faculty, allameh tabataba'i university, Tehran, Iran
Introduction: Governments are expected to adopt proper policies to promote health indicators and to control and decline social harms. However, current social harms statistics and types as well as age range of people who are involved in them show an unsuitable situation. Lack of convenient policy underlies poor interdisciplinary work, inadequate resource management, and arbitrary decision. There are many barriers which prevent social harms to be well identified and figured out: politicians and the public must intend and demand special consideration towards social harms; media activists should be concerned about it instead of focusing only on trivial or unsolvable topics; remarkable research evidence must be provided, and social harms must be well conceptualized as they vary time to time and place to place. The present study has been conducted to provide a list of recommended policies in order to control social harms in Iran, utilizing experts' opinions.

Methods:This is a qualitative and applied-developmental research study, conducted implementing a Delphi method. Delphi is a systematic data gathering method through which experts' opinions are obtained as regards a particular subject or question. In this study, during three rounds, experts answered written questions anonymously. The participants could see feedbacks of others and change or insist on their viewpoints. Finally, the research team continued the procedure until they felt that relative consensus has 


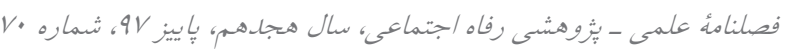

Social Welfare Quarterly, Vol 18, Fall 2018, No 70

been reached Twenty experts were asked to participate in the study. The experts were selected based on some criteria that could enable researchers to reach the study goals. They all had academic and scientific reputation, and they were also nationally known for their works on the topics related to the present study, either in social harms field directly or germane areas, such as sociology, social health, social work, social policy, economics, etc. They had also prominent practical experience in the fields that assured researchers that they are knowledgeable in the study topic. Since this method is inherently time consuming, the participants should have been provided with sufficient time to answer and get to know the topic. All recommended parts of Delphi method including controlled feedback, results analysis, and consensus were respected until the best possible agreement was reached.

Findings: Results were discovered differently in any round. In pre-round stage, one single open question was posed and 52 policies were taken out. In order to purify the received responses, 48 items were sent back to the participants. In the next rounds 31 policies were agreed upon and in the last round, experts noted that one of the items must have been divided into two, accordingly 32 policies were identified, and it was assessed and pointed out that the participants have agreed on 32 policies. Some of the most prioritized subjects were identified as, continuous monitoring of social harms, attention to community-based approaches, special attention to economic issues, attention to expanding alternative dispute resolution, developing happiness and hope, inter-organizational cooperation, attention to religious and social values, futurism, attention to high-risk areas, removing parallel and ineffective organizational structures, continuous assessment of social health, providing social and cultural attachment for programs, attention to educational centers, training specialized and professional persons, attention to virtual space and social media, healthy lifestyle, social identity, improving health-care, social support promotion, social inclusion, social responsibility and social demanding, attention to social responsibility of corporations, decreasing workplace stress, using mass media, using capacity of urban and rural management system, sense of social security, recreations, occupational training and empowerment, international communication and insurance coverage. 


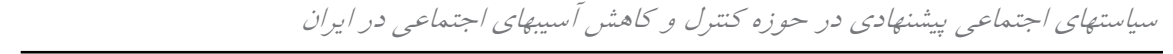

Suggested Social Policies to Control Social Harms in Iran

Discussion: Based on the findings, it can be claimed that despite all the efforts that have been made, there is still a long way to go to reach a satisfactory point to be able tackle social harms. Results of the present study revealed that except for addiction field that has already been made, macro-level social policy as regards social harms seems necessary to be built. Just by taking a macro-level policy into account, it will be possible to design pathways to avoid arbitrary decision making, to get all capacities, either in GO or NGO parts together, to begin an interorganizational coordination, to manage sources effectively, to determine priorities for policy making, to administer programs comprehensively, inclusively, and adequately, and finally, to do a better work division among related organizations at different levels. It is, of course, a noticeable progress that high ranking politicians did acknowledge that we are still several years behind compared to the way social harms change, since it helps scholars and managers to address the problems and find ways to solve them. Since social issues are interrelated, governments are supposed to make policies by which all indicators of health, including social health indicators become continuously investigated and along with changes of social issues, particularly social harms, policies become flexibly modified. Media and civil society would be good partners for governments to adopt and implement policies against social harms.

Keywords: development program, social harms, social policy, social security, social work 
Social Welfare Quarterly, Vol 18, Fall 2018, No 70

\section{مقدمه}

جوامع در طول حيات خود با مسائل و مشكلات مختلفى در حوزههاى اقتصادى، سياسى، فرهنكى و يا اجتماعى مواجه مىشوند. در حوزه اجتماعى نيز اين مشكلات مىتواند در عرصههاى مختلفى همجِون آسيبهاى اجتماعى ايجاد شود و بهتناسب انواع آن تمهيدات متعددى جهت كنترل و كاهش آنها اتخاذ مىشود. جامعهايران نيز از اين قاعده مستثنى نبوده و نخواهد بود. به همين دليل با وجود همه تمهيدات اتخاذشده و اقدامات انجام شده در عرصههاى سياستخارى و اجرايى امروز شاهد شرايطى در كشور هستيم كه ايجاب مى كند به اين موضوع توجه بيشتر شود. هنگامى كه جامعه دجار آسيب شود با مجموعهاى از يديدهها روبهرو مىشويم كه مىتوان آنها را در سطح فردى اندازه گيرى كرد مثلاينكه: (ادرصدى از

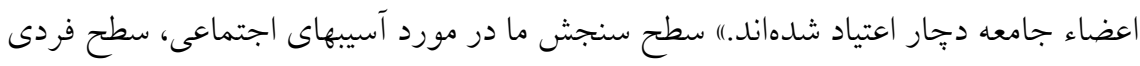
است ولى درواقع جامعه دجار آسيب شده است و بازتاب آن را بهصورت آسيبهاى اجتماعى نشان مىدهد، بنابراين سرمنشأ آسيبهاى اجتماعى در تركخوردن رابطه يا شكست روابط اجتماعى و عدم توانايى جامعه در منسجمكردن خود است. گر جّه به نظر مىرسد در بررسى اين حوزه نخاه تكبعدى نمىتواند كاملا صحيح قلمداد شود و لازم است نخاه همهجانبه در اين حوزه داشته باشيم و هم عوامل فردى، هم عوامل خانوادگى و هم عو امل اجتماعى در كتترل و كاهش آسيبهاى اجتماعى تأثير خذار هستند.

آسيبهاى اجتماعى يديدههاى متنوع، نسبى و متغيرند. يرخاشخرى و جنايت، خودكشى،

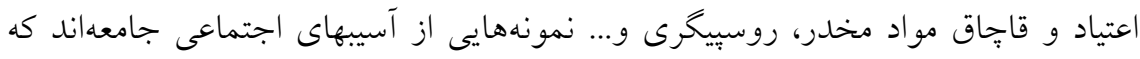
كم و كيف آنها برحسب زمان و مكان (يعنى حال نسبت به گذشته و در شهرها نسبت به روستاها) تغيير مى كنند، بنابراين، آنجهه امروز در يك جامعه خاص آسيب يا كجروى تلقى مىشود ممكن است فردا در همين جامعه يا همين امروز در جامعهاى ديخر آسيب يا كجروى 
سياستهاى اجتماعى بشئهادى در حوزه كترل و كاهش آسيبهاى اجتماعى در ايران

Suggested Social Policies to Control Social Harms in Iran

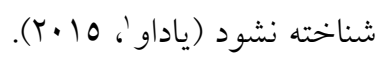

تأملى بر وضعيت كشور در اين حوزه نشان مىدهد كه وضعيت جامعه ايران در حوزه

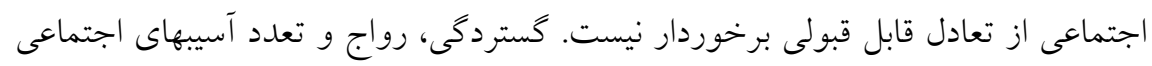

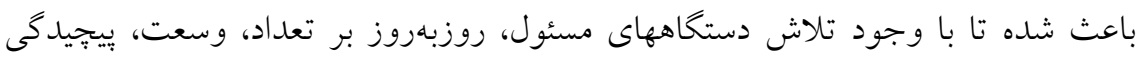

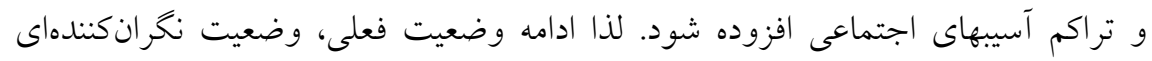

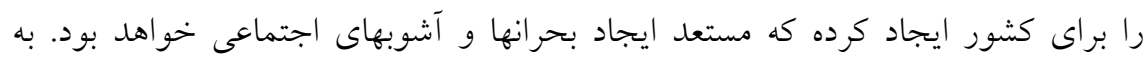

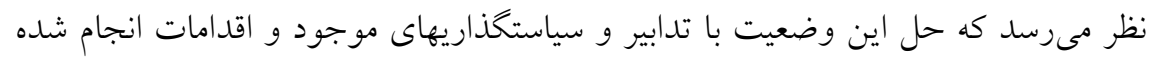

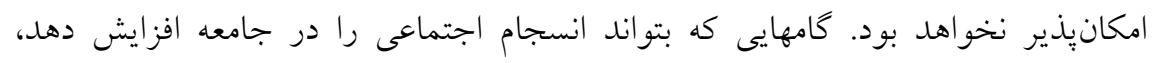

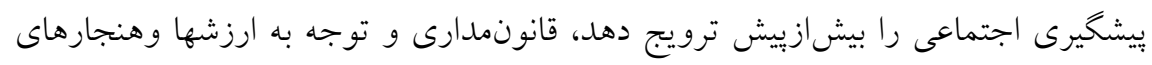

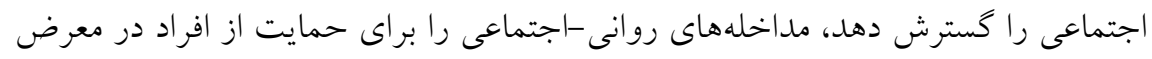

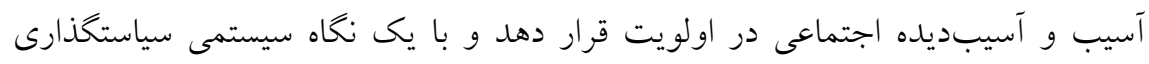

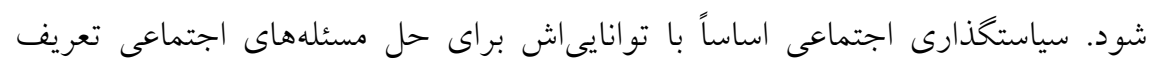

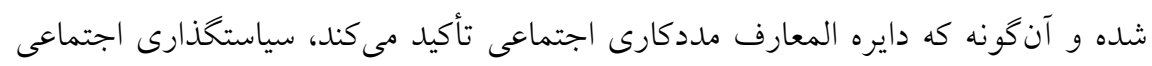

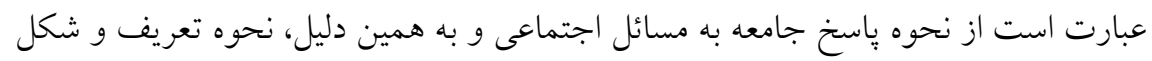

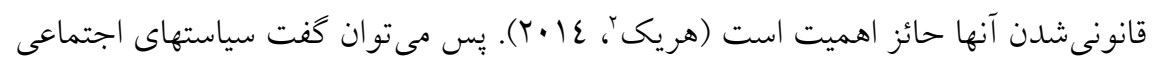

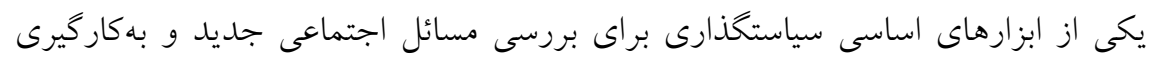

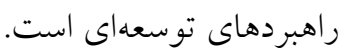
اين باور وجود دارد كه درنتيجه كسترش آسيبهاى اجتماعى در كشور هم فرد، هم

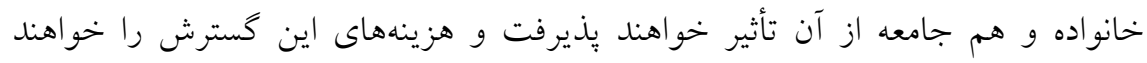

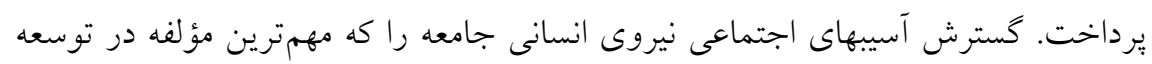

1 Yadav

2 Herrick 
هر كشور محسوب مىشود نابود خواهد كرد. بدون شك جامعلايى كه در آن نيروى انسانى

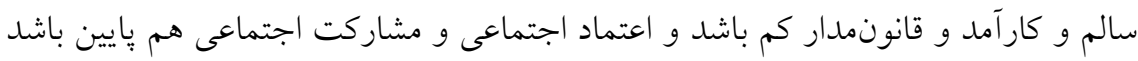

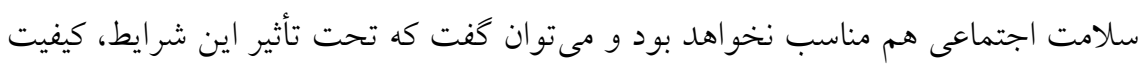

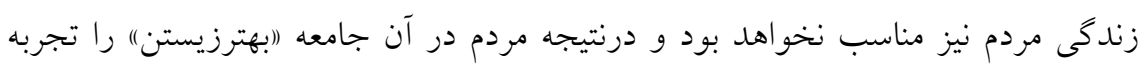
نخو اهند كرد. غفلت ديرينه در توجه به اين موضوع با رويكرد اجتماعى و اتخاذ سياستهاى مناسب درد

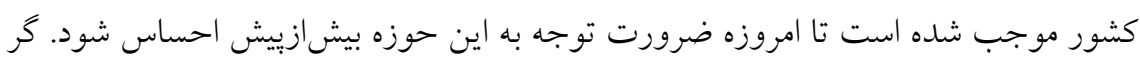

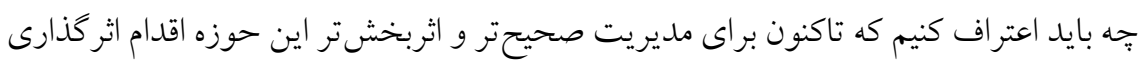

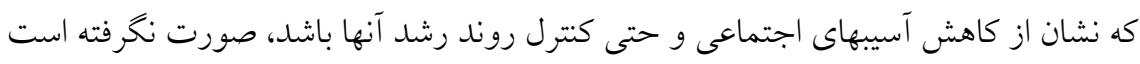

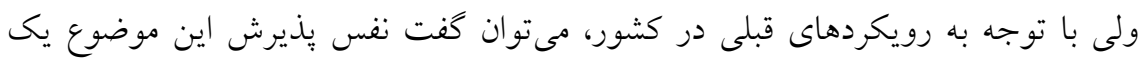

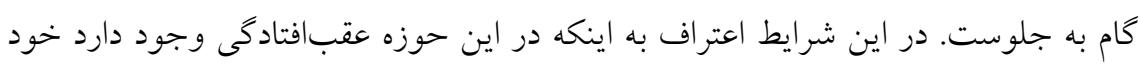

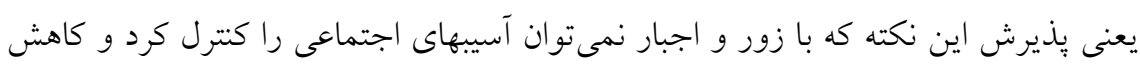
داد. تجربه نويسندكان در بيش از دو دهه در كشور در اين حوزه كه عموماً صحبت كردن إنهار

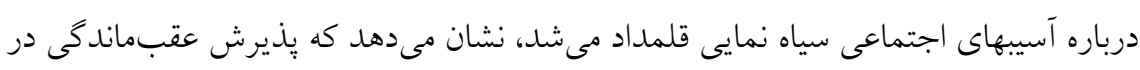
حوزه آسيبهاى اجتماعى توسط مسئولان كشور بايد يك فرصت تلقى شود تا بتوان با رويكرد اجتماعى و علمى در حوزه آسيبهاى اجتماعى سياستخذارى شوده.

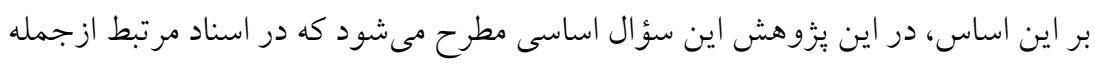

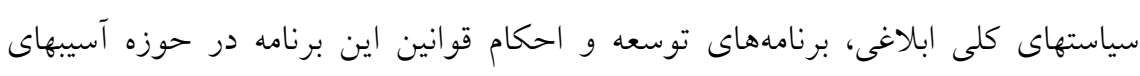

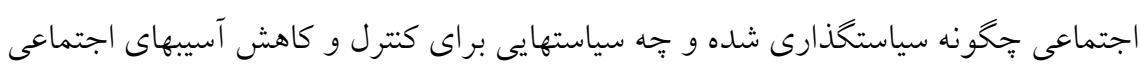

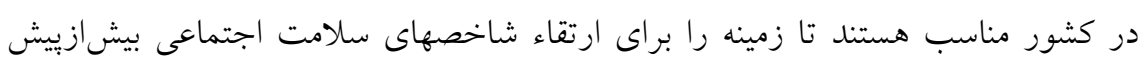

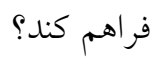




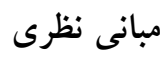

مغهوم آسيب اجتماعى اساساً بركرفته از ادبيات يزشكى بوده و در يك نياه اجمالى

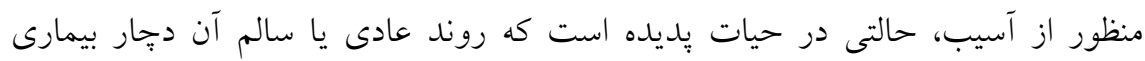

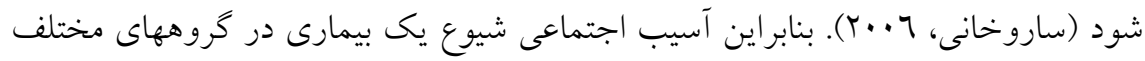

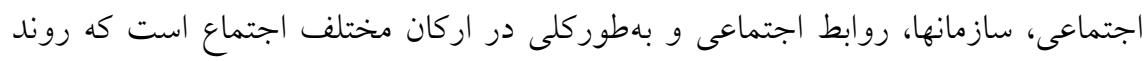

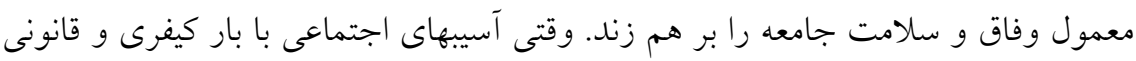

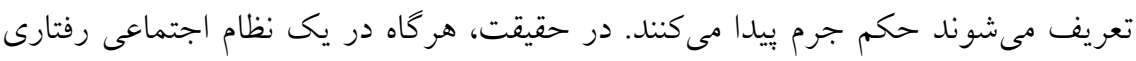

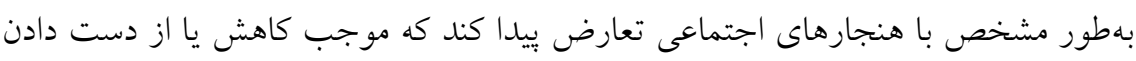

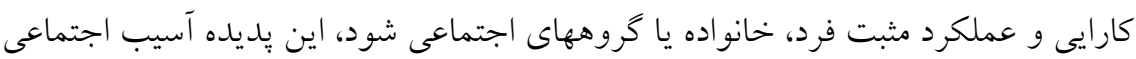

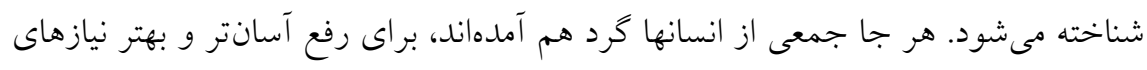

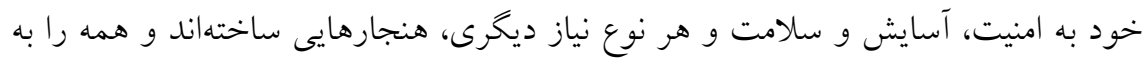

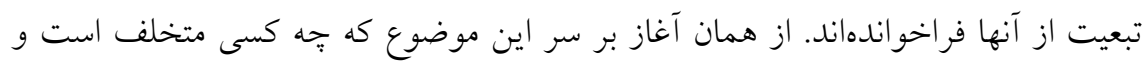

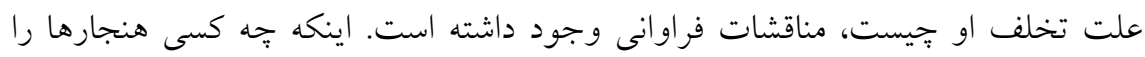

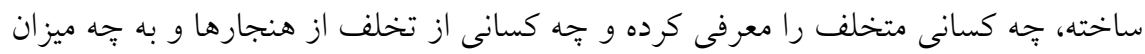

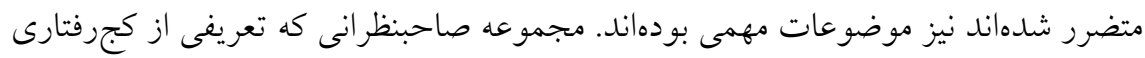

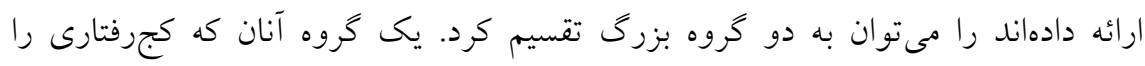

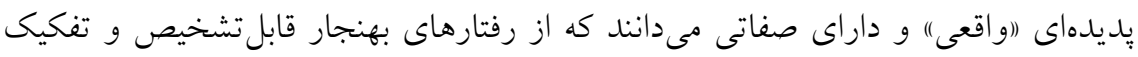

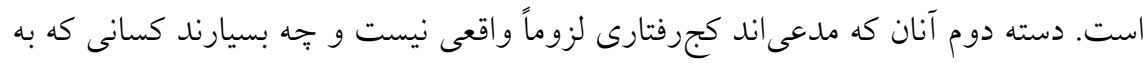

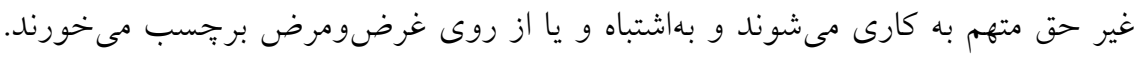

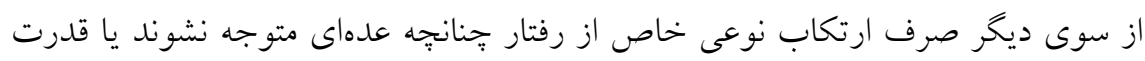

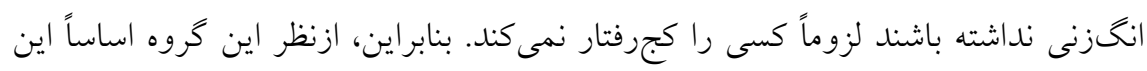

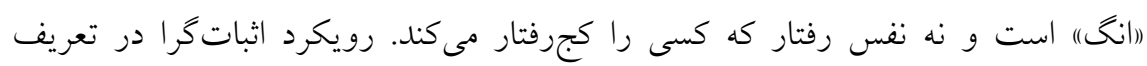


Social Welfare Quarterly, Vol 18, Fall 2018, No 70

كجرفتارى سه فرض اصلى دارد كه به (مطلق گرايى)، (اعين گرايى") و (جبر گرايى") معروف

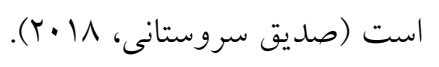

همجنين بر اساس اين رويكرد تلفيقى كجرفتارى نه آن جيزى است كه هر يكى از آن دو بهتنهايى ادعا مى كنند، بلكه شايد تلفيقى از هر دو رويكرد به واقعيت كجرفتارى نزديكتر است. بهبيانديخر، كجرفتارى هم واقعيت دارد و هم يك انخ است و يكى نمىتو اند بدون ديخرى وجود داشته باشد. اكر كنشى واقعى روى ندهد و يا انكى به كسى نخورد كه

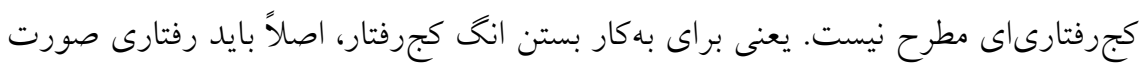
كرفته و هم براى درى آن رفتار بايد انخ كجرفتار به كار رفته باشد. البته بهكار بستن هر يك از دو رويكرد مطرحشده در مورد همه انواع كجرفتاريها هم درست نيست. رويكرد اثبات گرا براى توضيح انواع شديدتر كجرفتارى مثل قتل، تجاوز و سرقت مسلحانه مناسبت دارد و رويكرد برساخت كرا بيشتر در تبيين انواع خفيفتر كجرفتاريها مثل اعتياد به مواد مخدر و خودفروشى به كار مى آيد (صديق سروستانى، 11 إY). نتيجه آنكه با توجه به كليت هنجارهاى اجتماعى، توافق عموم در تعيين و تعريف اينكه كجرفتارى جيست نقش بسيار مؤثرى دارد و به همين دليل كجرفتارى را بايد بهعنوان رويدادى كه بر طيفبين دو قطب همنوايى كامل و كجرفتارى كامل به وقوع مى بيوندد دانست كه بهويزه در جوامعى كه به لحاظ فرهنكى و سياسى متكثرند، بيش از آنكه يديده متنوعى باشد، مدرج است. بدون شك خروج از شرايطى كه منجر به شيوع آسيبهاى اجتماعى شود نيازمند اتخاذ سياستهاى مناسب و برنامهريزيهاى كارآمد و اثربخش هستند به همين دليل موضوع

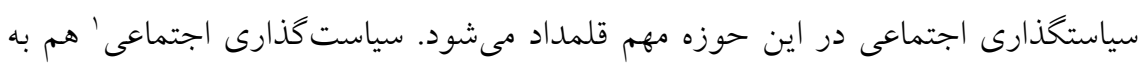
مجموعه اقدامات مربوط به مقابله با مشكالات اجتماعى و هم بهعنوان رشتهاى دانشخاهى به

1. social policy 
مطالعه اين اقدامات و بافت' اجتماعى كه در آن شكل مى گيرند دلالت دارد.

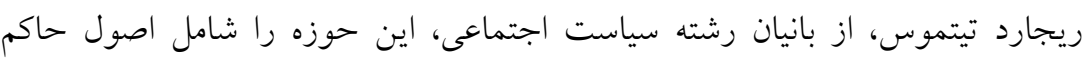
بر فعاليتهاى معطوف به اهداف مشخص مىداند و عنوان مى كند كه سياستخذارى (اكنش رئش مربوط به ابزارها و اهداف را مشخص مىكند و بنابراين بر تغيير دلالت مىكند (غفارى

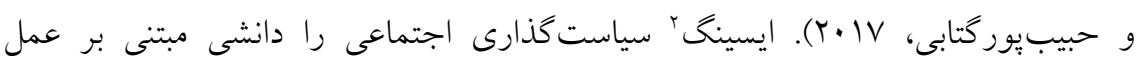
و يك حوزه مستقل مىداند كه بهطور نظاممند و تحليلى به بررسى آن دسته از اعمال سياسى مى يردازد كه معطوف به وضعيت زندگى (موقعيت اقتصادى و اجتماعى گروههاى

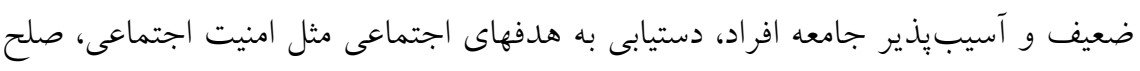
اجتماعى و عدالت اجتماعى) و مقابله با خطرهايى است كه حيات انسانى را تهديد مى كند. او بهكار بستن شناخت و آكاهى درباره ضرورت، مقدمات، امكانات، هزينهها و آثار و مسائل

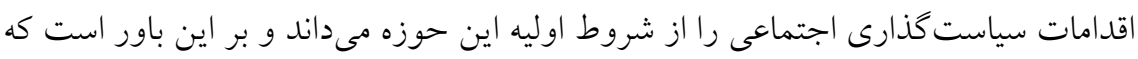

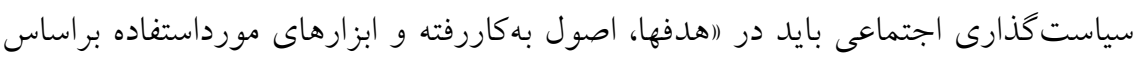

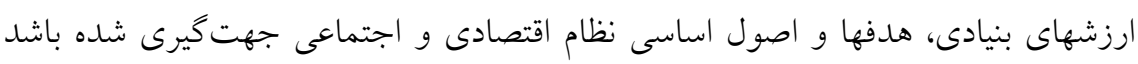

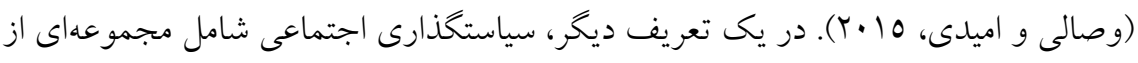

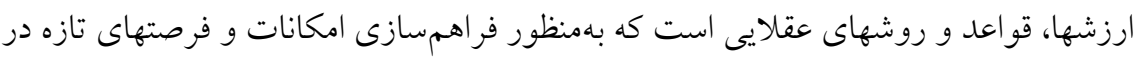

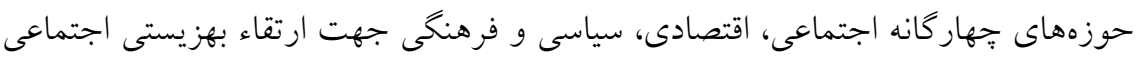

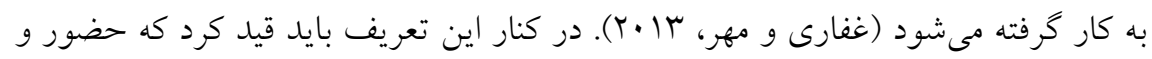

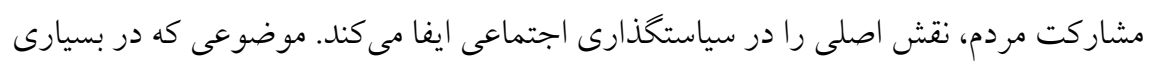
مواقع ناديده كرفته مىشود. سياستخذارى اخرجه مبتنى بر يزوهشها و براى مردم انجام مى يذيرد اما بيشتر حضور و 
مشاركت عمو مى در روند مشخص كردن سرفصلهاى سياست گذارى است و تدوين سياستها، محصول يك فرايند نخبه گرايانه است. بر اين اساس، افراد اندكى در تدوين و تنظيم ساختار سياستها دخيل هستند. همجنين انتظار مىرود كه حجم بيشتر كار در خارج از انظار عمومى صورت گيرد. نخارش سياستها طى مراحل بروكراتيك ادارى، در اتاقهاى كميتههاى قانون گذارى، در جلسات هيئتهاى ذىصلاح، حاصل مىشود. بهعبارتديخر معمولاً

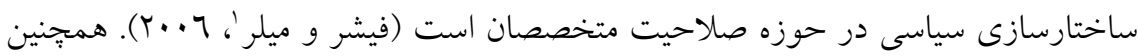

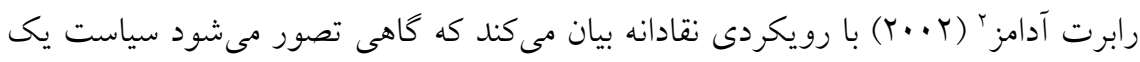
راهبرد نظاممند و منسجم است كه منجر به برنامههاى اقدام مستقيم و عملياتى مىشود. اين تصور اخر جهه ممكن است جذاب باشد اما درست نيست. به عقيده وى سياستخارى يك نخاه برخاسته از عقلكرايى و منطق به فرايند برنامهريزى و تدوين سياستهاست. او بر وجه

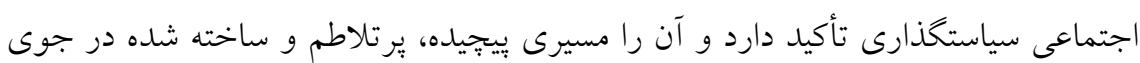
از تنشهاى بين نيروهاى رقيب معرفى مى كند. بالداى" (ع (Y. (Y)، هدف سياست گذارى اجتماعى را كاهش نابر ابرى و بهبود رفاه انسانى مى داند. نخست به اين دليل كه نابر ابرى و رفاه انسانى يك مسئله اخلاقى است. جون به لحاظ اخلاقى، وجود شكاف بزرگ در جامعه ميان فقير و غنى قابل دفاع و توجيه نيست. دوم اينكه، نابرابرى و رفاه انسانى به اين دليل در سياست گذارى اجتماعى مهماند كه بهطور مستقيم بر شهروندى تأثير مى گذارند. زيرا انسانهاى محروم، امكان استفاده از حقوق شهروندى خود را ندارند. بنابراين حتى در جوامعى كه حق سياسى به رسميت شناخته شده است، رفاه محدود

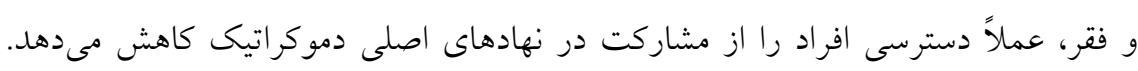
بنابراين در سطح ملى نابرابرى به حقوق شهروندى افراد لطمه وارد مى كند.

1 Fischer and Miller

2 Robert Adams

3 Baldock 
بلهطوركلى سياست كذارى اجتماعى مجموعهاى از قوانين، مقررات، نهادها و اقدامات

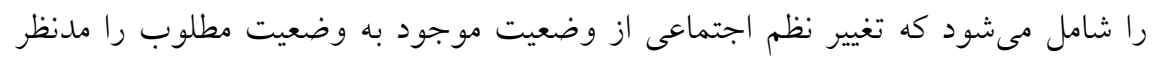

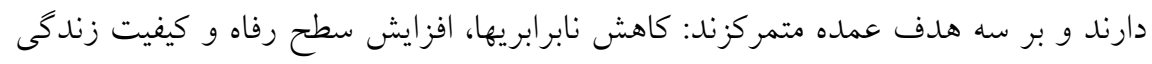

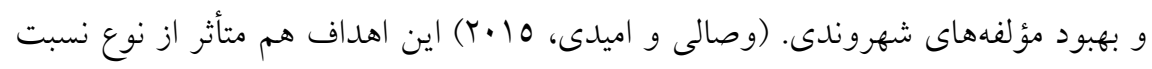

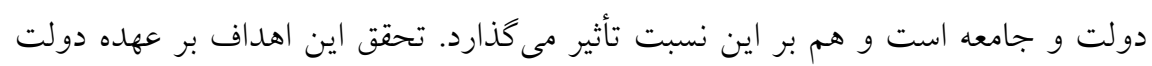

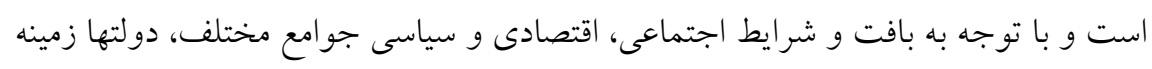

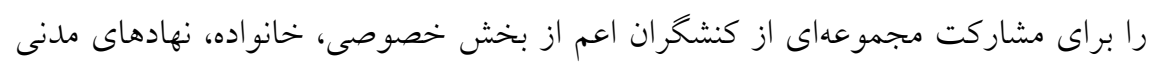

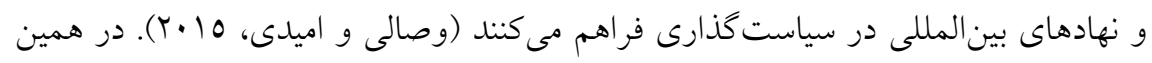
رابطه بر مفهوم توسعه اجتماعى بهعنوان بخش مهمى از فرايند توسعه تأكيد شده و اساساً

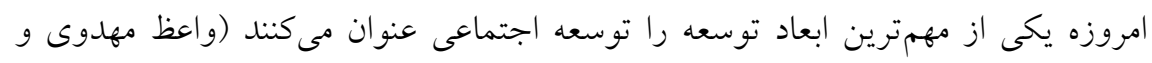

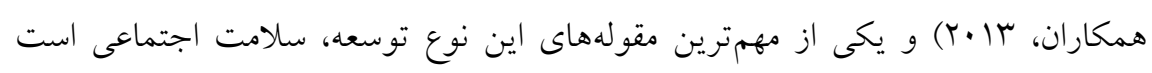

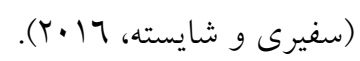

در ادبيات موضوع، كاهى سلامت اجتماعى از دو مفهوم سازگارى اجتماعى (به معناى

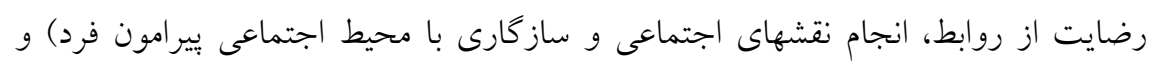

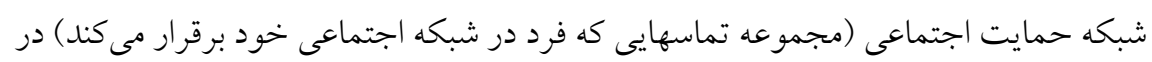

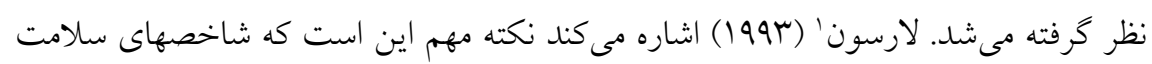

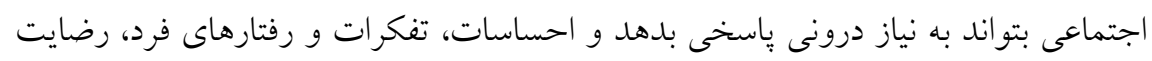

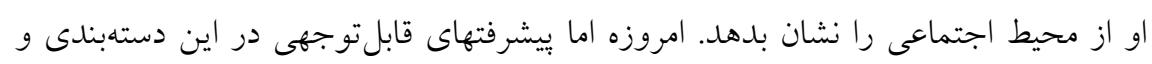

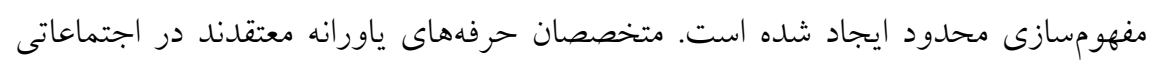

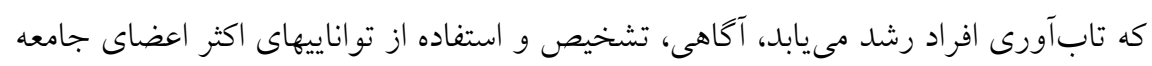

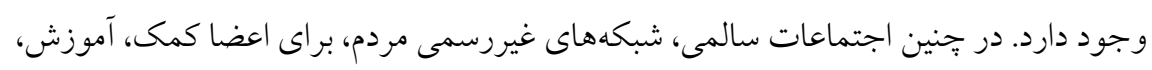


Social Welfare Quarterly, Vol 18, Fall 2018, No 70

حمايت و دلكرمى فراهم مى كنند (كَليكن'، · · (Y). بعد اجتماعى سلامت در بركيرندة سطوح

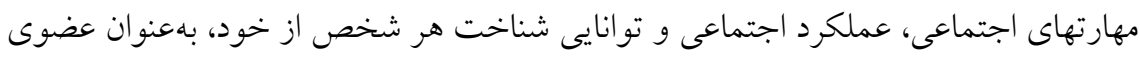

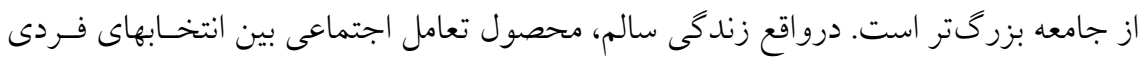

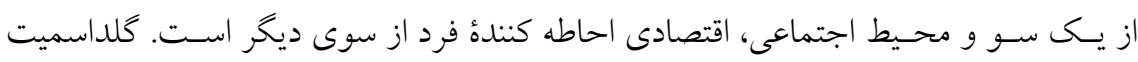
سلامت اجتماعى راعبارت از ارزيابى رفتارهاى معنىدار مثبت و منفى فرد در ارتباط با ديخران

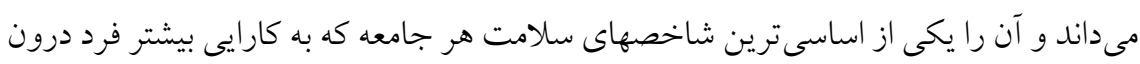

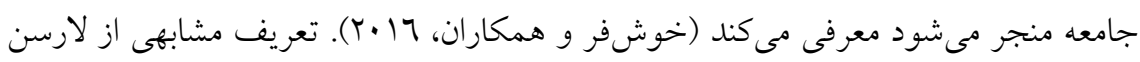

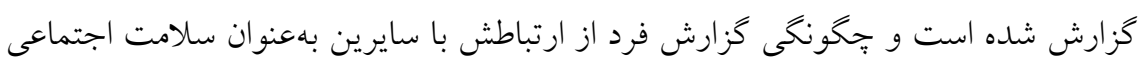

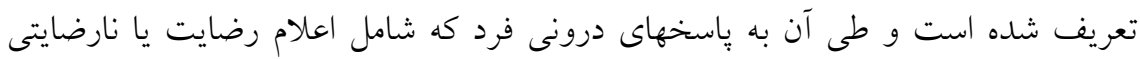
از محيط اجتماعى زندگىاش مى شود سلامت اجتماعى كفته مىشود (سميعى و همكاران،

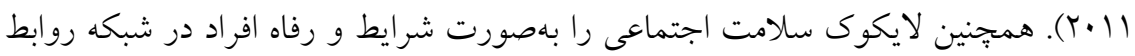

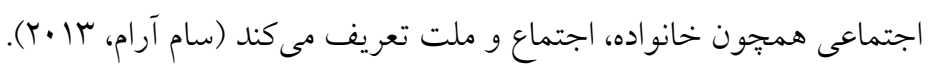

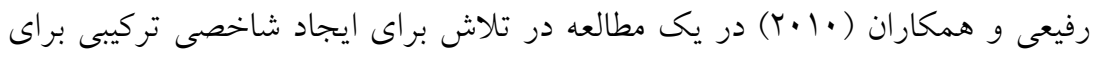

سلامت اجتماعى در ايران، سه دسته از تعاريف را شناسايى مى كنند كه عبارتند ازي:

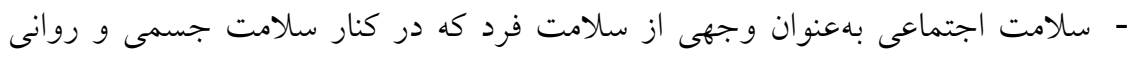

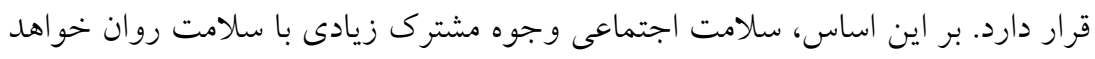

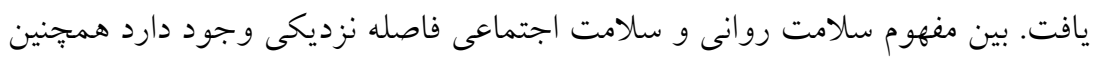

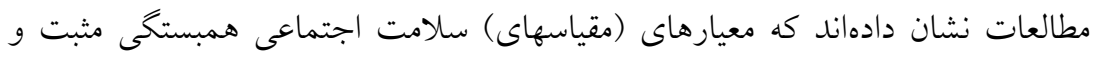
معتدلى با معيارهاى سلامتى روانى دارند.

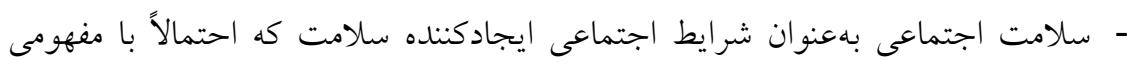
وسيع تر به نام تعيين كنندهاى اجتماعى سلامت قابل برابرى و همتراز است. 
- - سلامت اجتماعى بهمثابه جامعه سالم كه در آن بهطوركلى وضعيت اجتماعى بهترى را

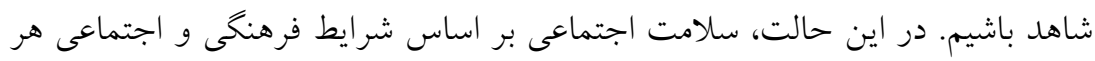

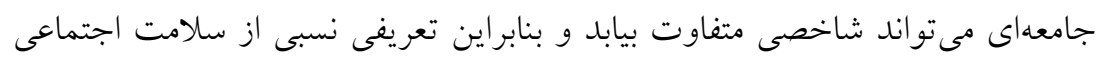
مى توان ارائه كرد.

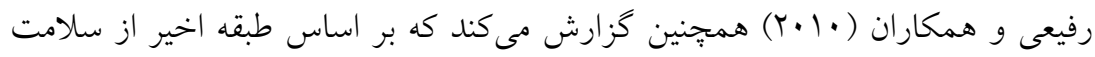

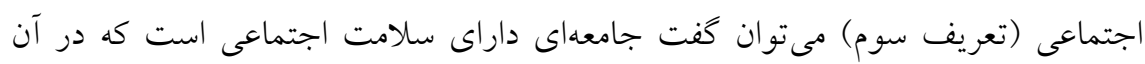
فقر، خشونت، تبعيض جنسيتى و تبعيض قومى، نزادى و منطقهاى وجود نداشته باشد و در عوض، رشد جمعيت كتترل شده باشد، آزادى عقيده وجود داشته باشد، دسترسى بـ به وله

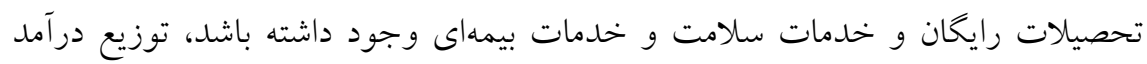
عادلانه باشد و مردمسالارى و نظارت مردم بر مردم و مردم بر دولت جريان داشته باشد.

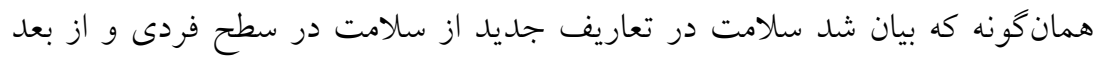

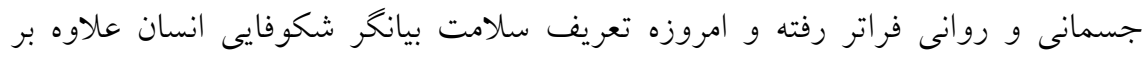
مواجهنبودن با بيمارى است. تعريف سلامت البته تا حدودى به حس مشترى اعضاى خرده

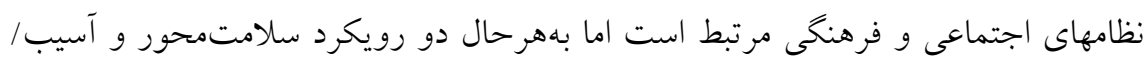
بيمارى محور در طول زمان در بررسى انسان اجتماعى به وجود آمدهاند (سام آرام، سا. (Y).

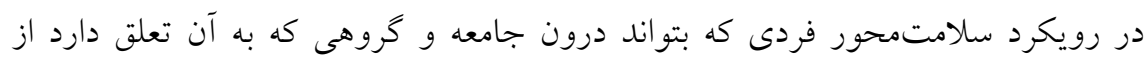

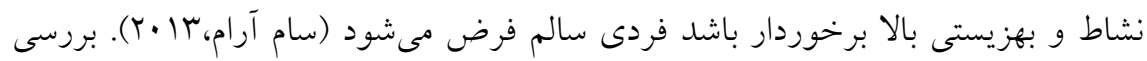

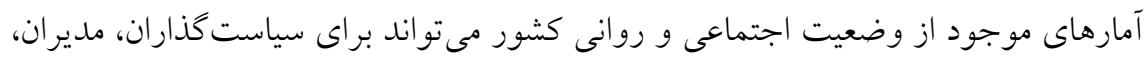

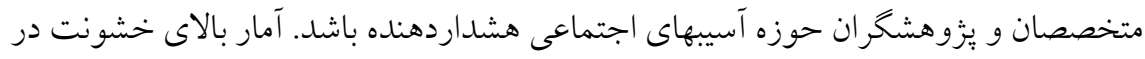

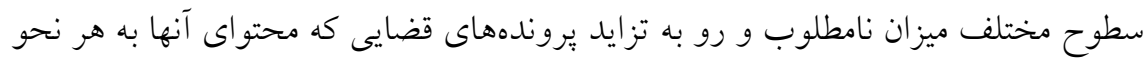

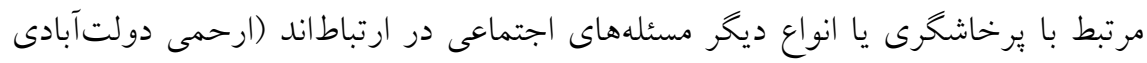

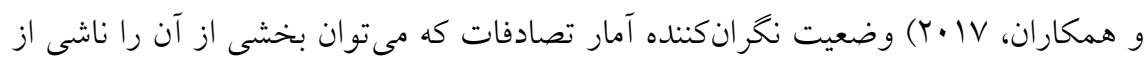


عدم مداراى اجتماعى، تضادها و تعارضات بيشرونده و حلنشده در ارتباطات بين فردى

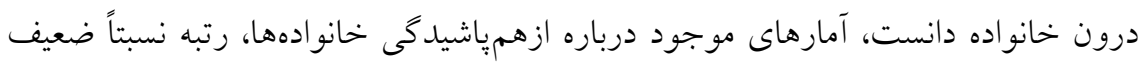
ايران در شاخصهاى مرتبط با نشاط و شادابى و بسيارى مصاديق ديخر مىتواند بيانكر لزوم توجه به شاخصهاى سلامت اجتماعى در كشور باشد جون همان گونه كه نشان داده شده است اين عاملها رابطهاى دوسويه با سلامت اجتماعى ايجاد مى كنند (سميعى و همكاران، II (Y). همان گونه كه ذكر شد جامعهاى را مىتوان با مفهومى كه از سلامت اجتماعى ارائه شد سالم خو اند كه رضايت و شادابى مردم در آن قابلرؤيت باشد. فقدان سلامت اجتماعى را مى توان نتيجه عدم جذب افراد در جارجيوبهاى اجتماعى و نتيجتاً عدم جامعهيذيرى صحيح آنها دانست. بنابراين مىتوان كفت سلامت اجتماعى عامل مهمى در كتترل آسيبهاى اجتماعى

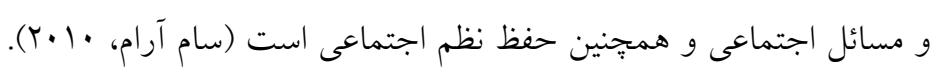

روش

يُّوهش در هر موضوع، به هر شكلى و در هر سطحى كه انجام شود، تلاشى منسجم و نظاممند در جهت توسعه دانش موجود درباره موضوعهايى است كه با آنها سروكار داريم. يزوهش كوششى است براى يافتن بهترين راهحلهاى ممكن در جهت حل مشكلات موجود در عرصههاى مختلف زندكى. همجنين، يزوهش فعاليتى منسجم براى رسيدن به شناختى روشنتر از مفاهيم بيرامونمان است. با توجه به اينكه اين تحقيق موضوعمحور است روش مورداستفاده (اروش كيفى" انتخاب شده است كه يافتههاى آن از طريق دادههاى آمارى و يا كمى حاصل نمى شود بلكه تلاشى است جهت توصيف غير كمى از موقعيتها و درك و تبيين يديدههاى يِيجيده اجتماعى از دادهاى كيفى استفاده مى كند و براى جمع آورى دادهها از تكنيك دلفى استفاده شده است. دلفى رويكرد يا روشى سيستماتيك در تحقيق براى استخراج نظرات از يك گروه 
متخصصان در مورد يك موضوع يا يك سؤال است و يا رسيدن به اجماع گروهى از طريق

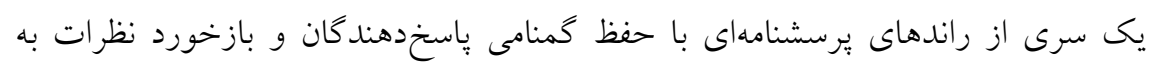

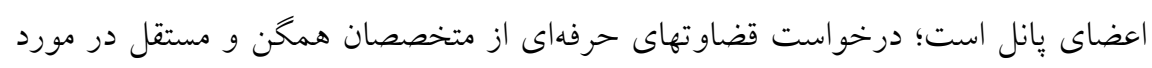

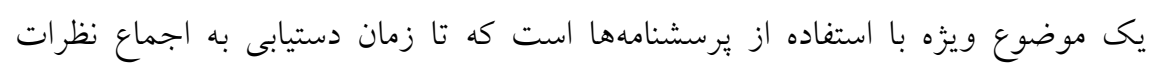

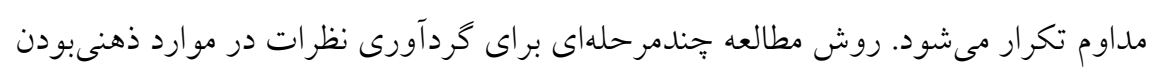

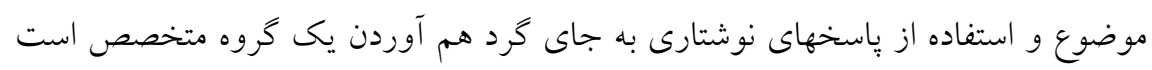

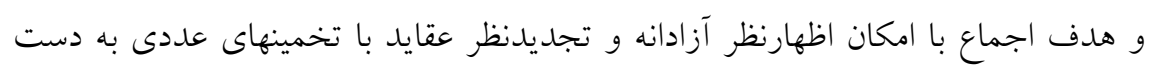

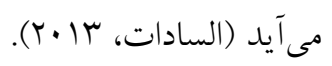

اجزاى اصلى دلفى شامل تكرار يا بازكويى يرسشنامه، متخصصان، بازخورد كترلشدهه،

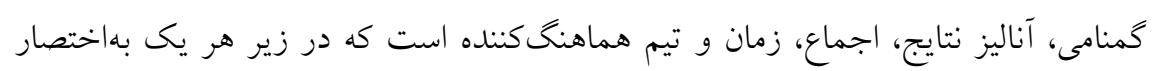
شرح داده مىشود: بازكويى يا تكرار: در اين تحقيق يك مرحله ييش راند و ب مرحله راند اصلى به انجام رسيده است. صلاحيت پانليستها: متخصصان شركتكننده در اين تحقيق، همخى از افراد برجسته و

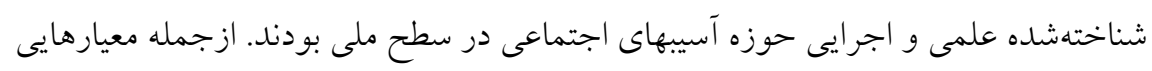

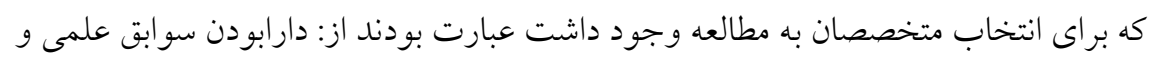

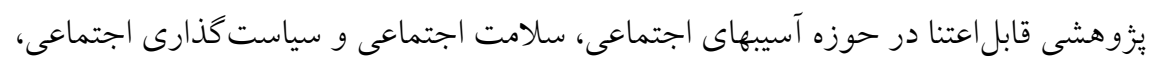

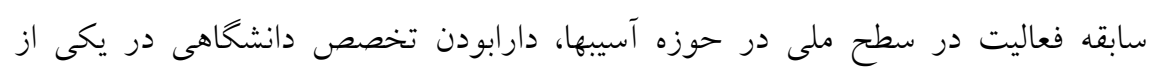

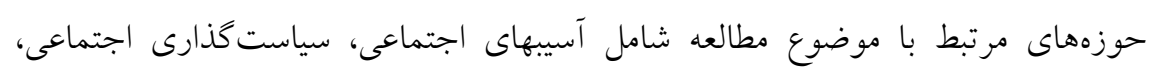
سلامت اجتماعى، سياست كذارى اقتصادى، مددكارى اجتماعى و رشتههاى مرتبط.

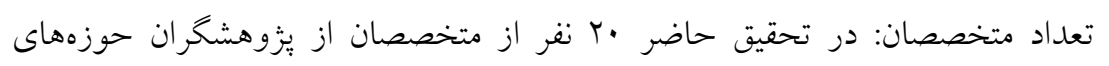

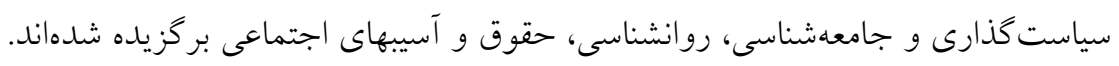


مشاركت كنندگان: در اين تحقيق مشاركت كنندگان مبتنى بر هدف و بر اساس تخصص و تجربهشان درزمينه موضوع تحقيق انتخاب شدهاند. بازخورد كنترلشده: در اين تحقيق همراه با برسشنامه راند بعدى نتايج راند قبلى در اختيار متخصصان قرار گرفته و طى نامهاى از آنها درخواست شد تا نتايج راند قبلى را مطالعه و سيس در خصوص راند بعدى نظردهى كنند.

معيارهاى نشاندهنده اجماع درصد آيتمها (رايجترين)، ثبات ياسخها و تفسير بر مبناى نظر متخصصان است. در نتايج مطالعات محدوده متفاوتى از سطح، اجماع اله تا . . ا درصد گزارش شده است. در اين تحقيق نيز اجماع بالاى •V درصد ملاك تصميم گيرى قرار گرفته است.

\section{يافته ها}

در اين تحقيق يافتهها در جهار مرحله به دست آمده است. در مرحله اول كه ييشراند بود ابتدا با يك سؤال باز از نخبگان خواسته شده بود تا سياستهاى مناسب براى كنترل و كاهش آسيبهاى اجتماعى در ايران را بنويسند كه درنهايت Or سياست بيشنهاد شد كه يس از تحليل محتوا درنهايت در مرحله اول ^ع سياست براى اعلام نظر براى آنان ارسال شد. يّ از تحليل اطلاعات اين مرحله، براى مرحله دوم اسب سياست براى نخبخان ارسال و از آنها خواسته شده بود كه نظرات خود را اعلام كند. بِ از تحليل اطلاعات اين مرحله و ارسال مجدد آن براى متخصصان، آنها بر جدا نوشته شدن يكى از سياستها اجماع كردند و درنهايت در مرحله سوم بr سياست تعيين شد. با استفاده از روش بودجهريزى از تعداد ·ل نفر از

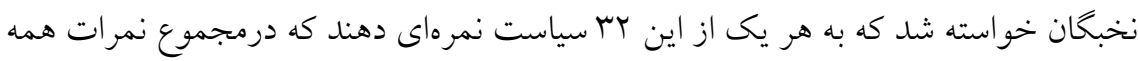
سياستها، بيش از ․ نباشد تا بتوان اولويتبندى سياستها را انجام داد كه يافتهها نشان داد كه اولويت سياستها به نسبت يافتههاى مرحله سوم تغيير اندكى داشته است. تأملى بر يافتههاى تحقيق گوياى اين نكته است كه با وجود اقدامات انجام شده در كشور در 
حوزه سياست گذاريهاى مرتبط با آسيبهاى اجتماعى نيز به داشتن سياستهاى اجتماعى مشخص

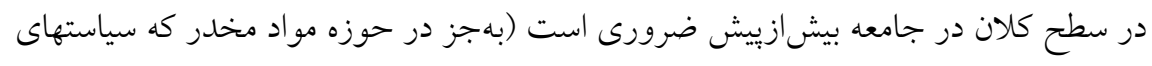

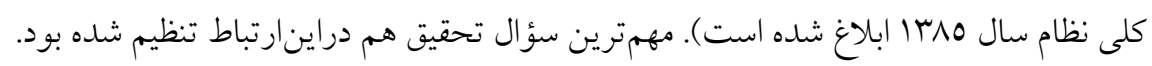

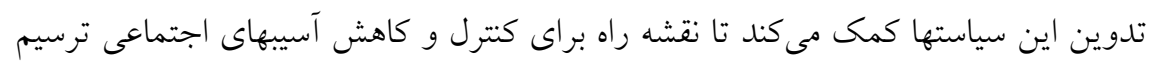

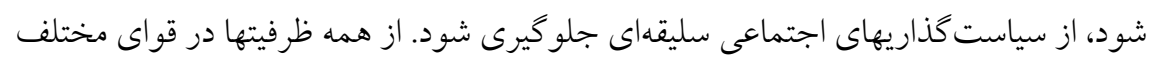

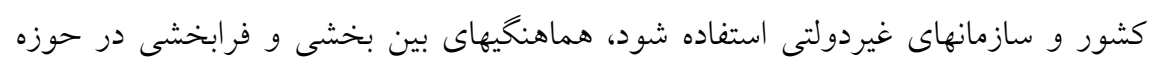

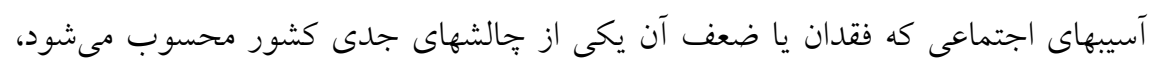

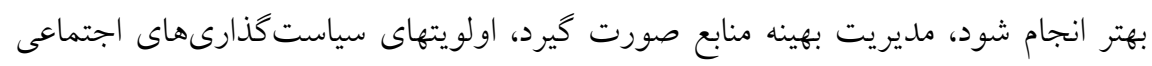

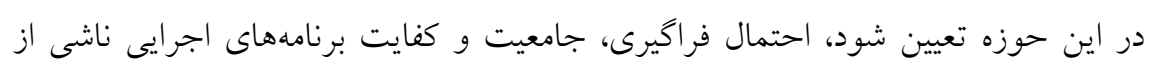

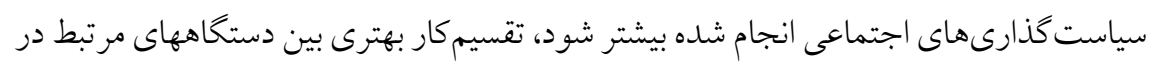
سطوح مختلف بيشخيرى از آسيبهاى اجتماعى صورت كيرد.

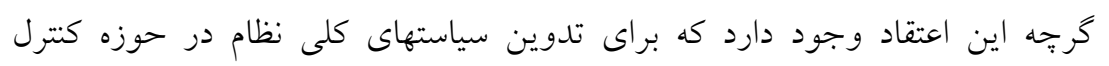

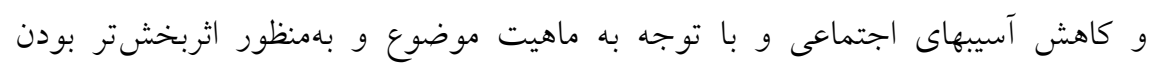

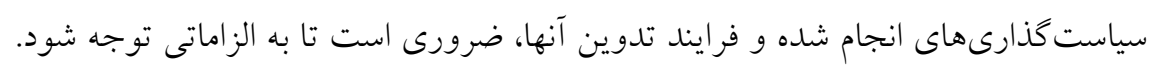

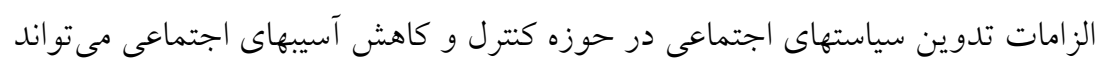

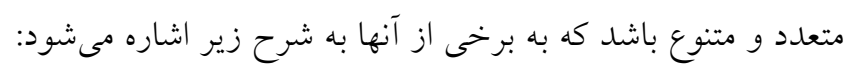

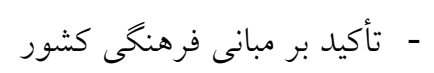

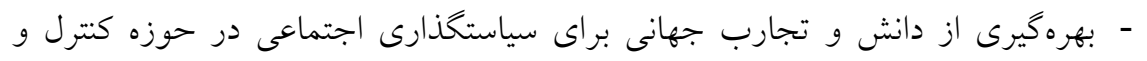

$$
\text { كاهش آسيبهاى اجتماعى (با رعايت شر ايط كشور-بومى دسازى) }
$$

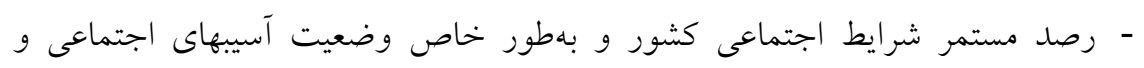

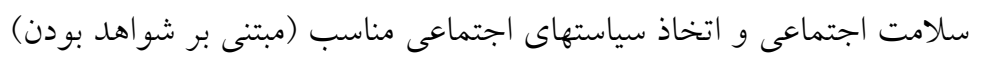

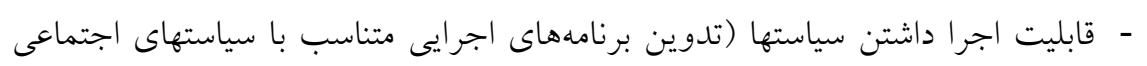


Social Welfare Quarterly, Vol 18, Fall 2018, No 70

اتخاذشده در حوزه آسيبهاى اجتماعى)

- استفاده از روشهاى علمى در تدوين سياستها - استفاده حداكثرى از ظرفيتهاى موجود (دولتى (قواى مختلف) و غيردولتى) مرتبط براى سياستخارى اجتماعى در اين حوزه - بررسى تأثيرات سياست گذارىهاى انجام شده در ساير حوزه ازجمله حوزههاى اقتصادى دئ

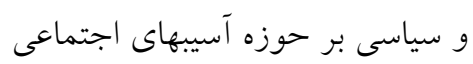
- توجه به رويكرد سلامت اجتماعى در سياست گذاريهاى اجتماعى در حوزه آسيبهاى اجتماعى إنى - توجه به آيندهنخرى اجتماعى براى سياست گذارى اجتماعى - در اختيار داشتن دادهها و اطلاعات موردنياز براى سياست گذارى - - در نظر داشتن امكانات كشور و تعيين انتظارات متناسب با توان جامعه - توجه به سطوح مختلف بيشخيرى از آسيبهاى اجتماعى در سياست كذاريهاى مرتبط با آسيبهاى اجتماعى

با توجه به موارد فوق درنهايت سياستهاى بيشنهادى كه نخبخان روى آنها اجماع كرده بودند به شرح زير، نهايى و جمعبندى شده است: ا. رصد علمى و مستمر آسيبهاى اجتماعى با توجه به شاخصهايى هميجون: نوع، شيوع و شدت r. اتخاذ و تقويت رويكردهاى اجتماعححور در برنامههاى ييشخيرى از آسيبهاى اجتماعى س. توجه ويزه به مسائل اقتصادى از طرق: الف) فراهمكردن زمينههاى سرمايه كذارى داخلى و خارجى، ب) اصلاح مكانيسمهاى مالياتى خصوصاً ماليات بر درآمد و دارايى، ج) فر اهم كردن زمينهاى كاهش سود واسطه گرى و دلالى و افزايش سود حاصل از توليد، 
د) آموزش كار آفرينى و مهارتهاى كار آفرينانه، ح) تقويت بخش حمايتى

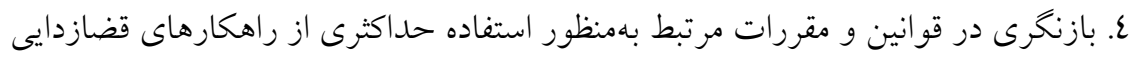

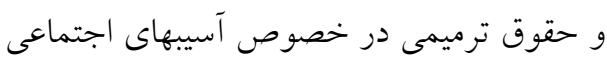

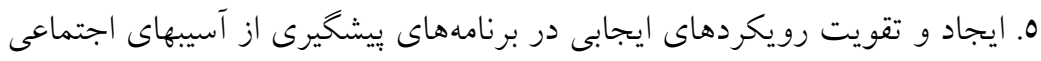

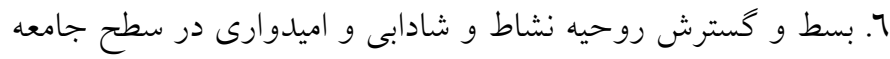

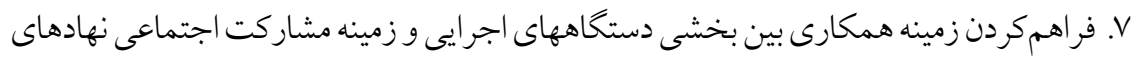

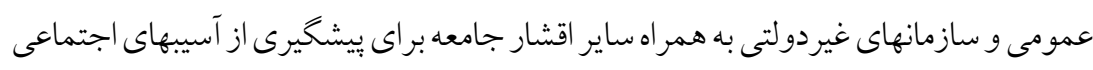

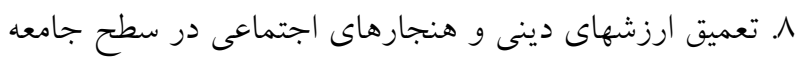

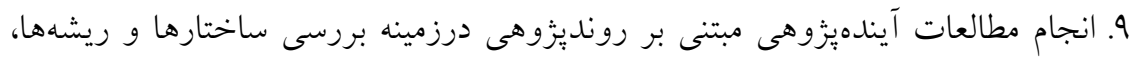

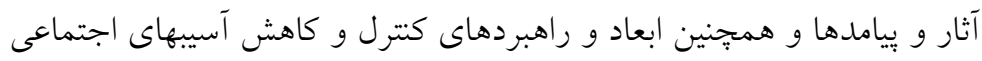

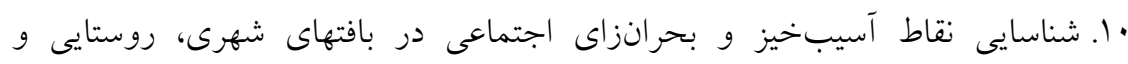

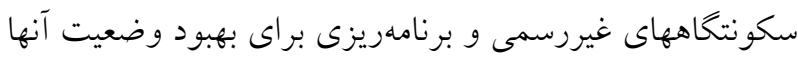

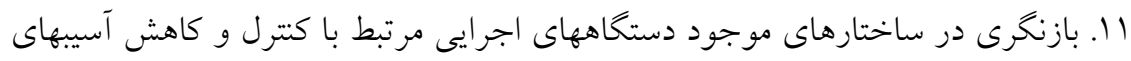

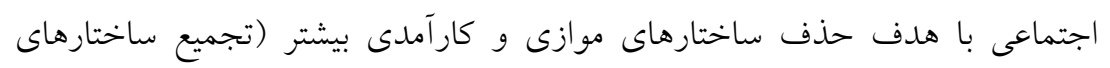
موجود) و تأمين منابع لازم

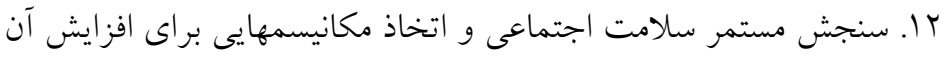

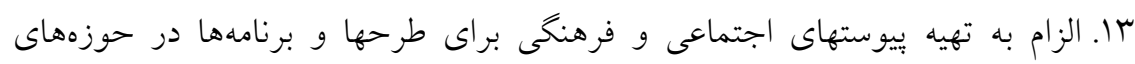
عمر انى و اقتصادى ع ا. استفاده از ظرفيتهاى مراكز و مؤسسات آموزشى ازجمله: مهدهاى كودى، مراكز

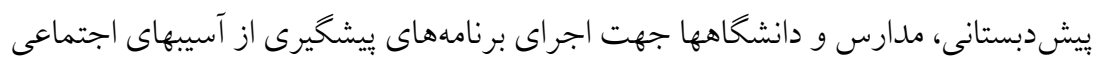

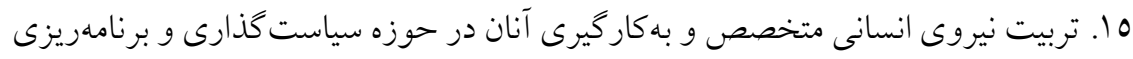

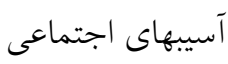


17 ا. استفاده از ظرفيت فضاى مجازى و شبكههاى اجتماعى براى اطلاعرسانى، آكاهسازى و

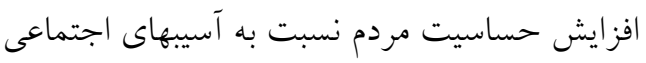

$$
\begin{aligned}
& \text { VIV IV ترويج سبك زندكى سلامتمحور }
\end{aligned}
$$

11. تقويت هويتهاى جمعى (دينى، ملى و قومى) بهمنظور افزايش انسجام و سرمايه اجتماعى سلى سلى

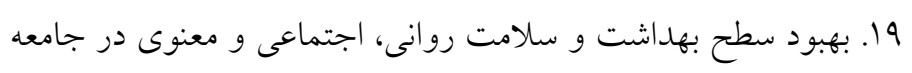

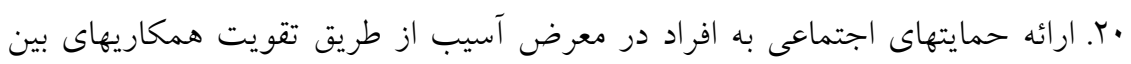

$$
\text { بخشى }
$$

آ ارائه حمايتهاى اجتماعى به افراد آسيبديده اجتماعى از طريق تقويت همكاريهاى بين

$$
\text { بخشى }
$$

r T. فراهم كردن زمينه هاى بازگشت آسيب ديدكان (بهبوديافته) اجتماعى به جامعه (ترويج

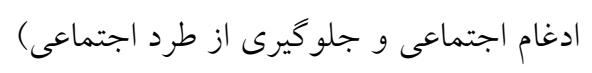

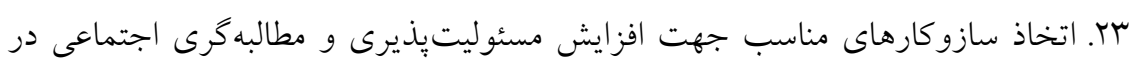

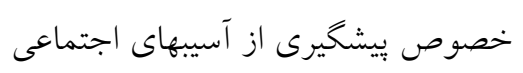

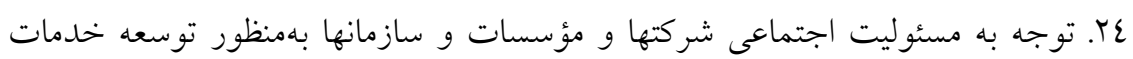

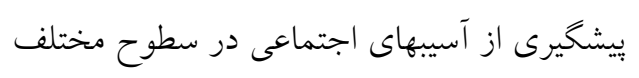

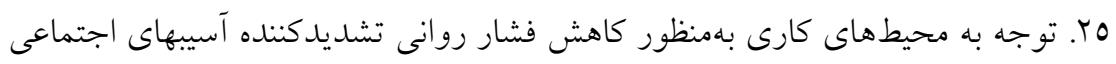

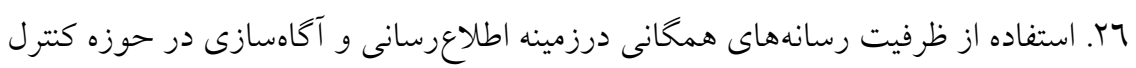

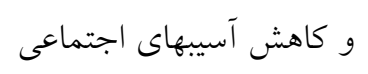

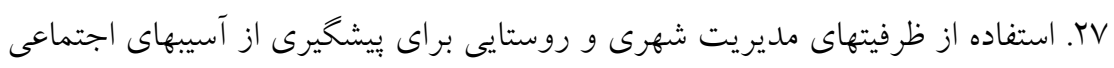

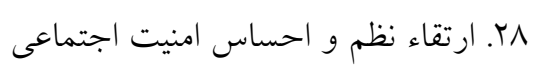

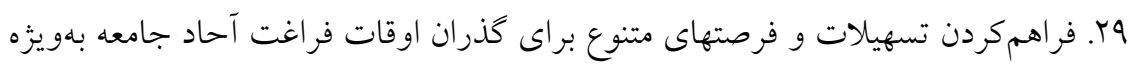

$$
\text { نوجوانان و جوانان }
$$


•ب. اتخاذ تدابير لازم براى حمايتهاى اجتماعى درزمينه آموزشهاى فنى و حرفهاى، اشتغال

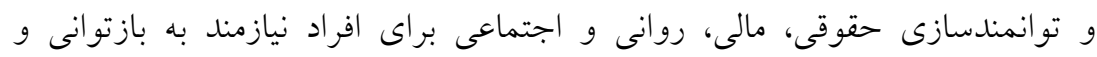
خانو ادههاى آنان اس. تعامل و همكارى بينالمللى در جهت تبادل اطلاعات و انتقال تجارب ساير كشورها

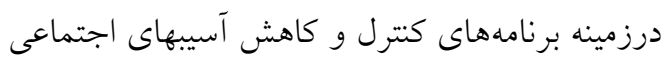

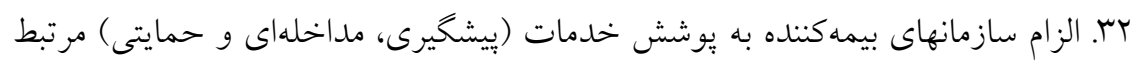

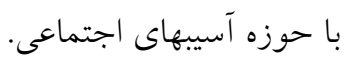
آنجها بهعنوان سياستهاى يِشنهادى براى كنترل و كاهش آسيبهاى اجتماعى در بالا آورده

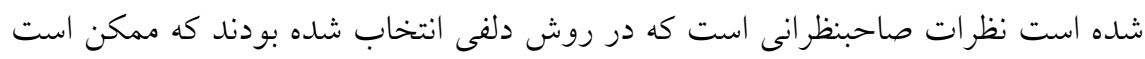
صاحبنظران ديخر نقدهايى هم بر اين سياستها باشد يا بتوانند تكميل كنئد.

\section{بحث}

همجنان كه كفته شد آسيبهاى اجتماعى ذاتاً ذوالابعاد هستند و آنَّونه كه از يافتها مشخص است مىتوان كفت سياستخذارى اجتماعى مرتبط با آسيبهاى اجتماعى در كشور از منظر سلامت اجتماعى بايد دربردارنده موارد متعددى باشد كه شامل رصد مستمر آسيبهاى مئيط

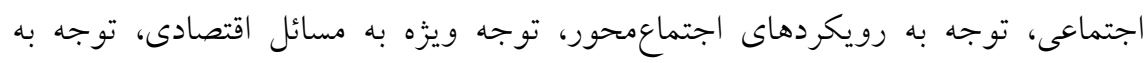

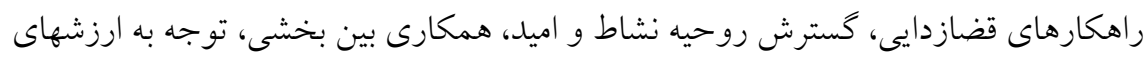

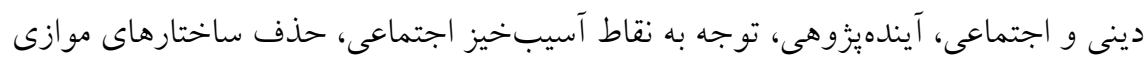

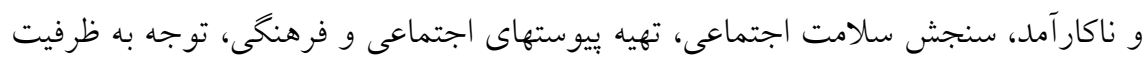
مر اكز آموزشى، تربيت نيروى متخصص، فضاى مجازى و شبكه هاى اجتماعى، سبكى زندكى

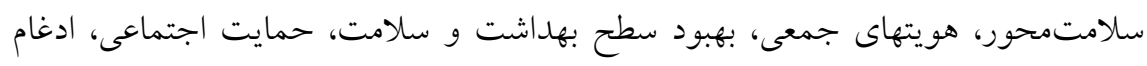

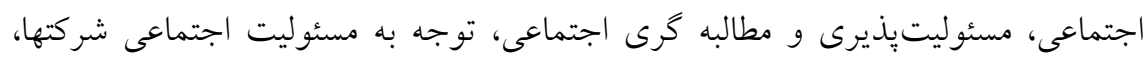


Social Welfare Quarterly, Vol 18, Fall 2018, No 70

كاهش فشار روانى محيطهاى كارى، استفاده از ظرفيت رسانهاى همخانى، استفاده از ظرفيتهاى مديريت شهرى و روستايى، نظم و احساس امنيت اجتماعى، اوقات فراغت، آموزشهاى فنى و حرفهاى، اشتغال و توانمندسازى تعامل بينالمللى و بوشش بيمهاى است. جانهارتل بيش از بيست سال قبل در خصوص سياستهاى اجتماعى كه مىتواند براى آسيبها و مسئلههاى اجتماعى اثر خذار باشد اظهارنظر كرده بود. به عقيده او، سياستخذارى اجتماعى نهفقط يك فرايند ساده بلكه يك موضوع نظرى، فرهنكى، تاريخى، ايدئولوزيك، ير اخماتيك و سياسى است (هارتل'، 1990). وى همجنين مفهوم سياست گذارى اجتماعى را براى دنياى قرن بيست و يكم مبتنى بر سه محور عمله تعريف كرد كه عبارت بودند از: بيمههاى اجتماعى، حمايتهاى دولتى و خدمات اجتماعى ب (هارتل، آسيبهاى اجتماعى يكى از موضوعاتى كه در كشور نخرانى زيادى ايجاد كرده و مىتو انند بر كيفيت زندگى مردم تأثير منفى بخذارند و افزايش آن در هر جامعه، نشانهاى از كاهش شاخصهاى سلامت اجتماعى و سرمايه اجتماعى محسوب مىشود. اين در حالى است كه يكى از وظايف دولتها فراهمسازى بسترهاى مناسب براى ارتقاء مستمر كيفيت زندكى

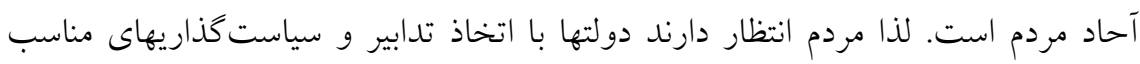
بتوانند زمينه تحقق اين انتظار را بيشازييش فراهم كنند. وجود نيروى انسانى سالم، كارآمد، قانونمدار، جامعهيذير (اجتماعى شده)، مسئوليتيذير و... بهعنوان يكى از مهمترين منابع توسعه در هر كشورى نيز لازمه تحقق عملى اين انتظار (وظيفه دولت) است كه دركيرشدن

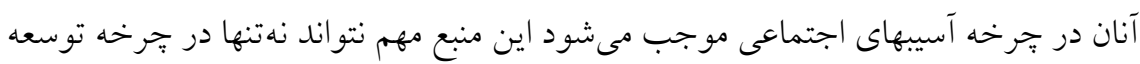
و سلامت اجتماعى اثربخش باشد بلكه هزينههاى دولت را در ايجاد امنيت و كنترل آنها

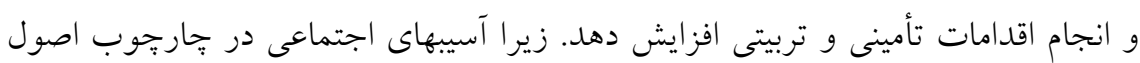


اخلاقى و قواعد عمل جمعى رسمى و غير رسمى جامعه قرار نمى گيرند و اين خارجوب

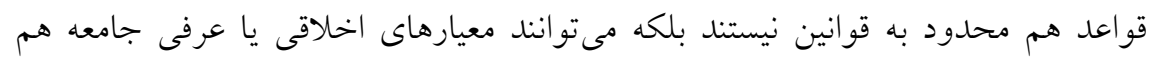

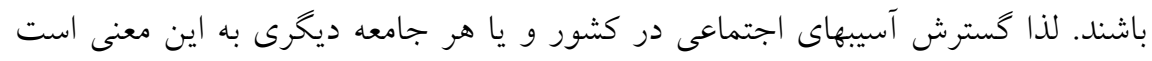

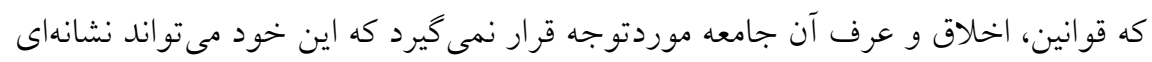
از ناكار آمدى دولتها در ايفاى وظيفهشان براى تحقق جامعهاى ايمن از منظر اجتماعى باشد.

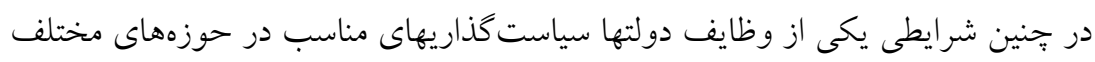

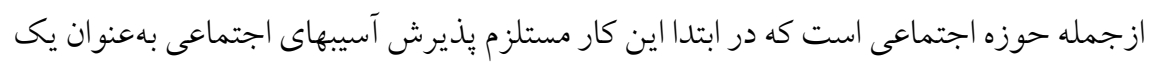

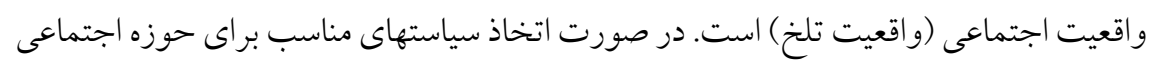

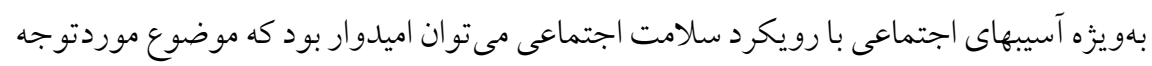

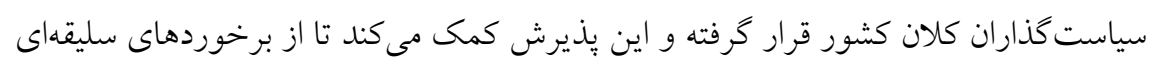

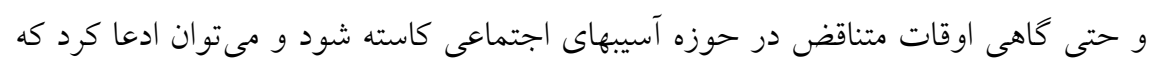

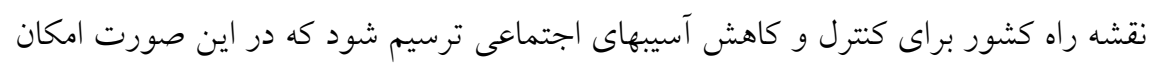

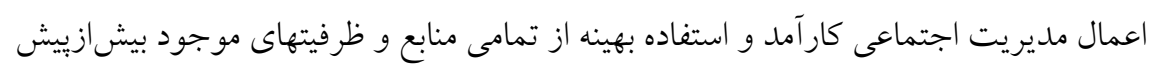

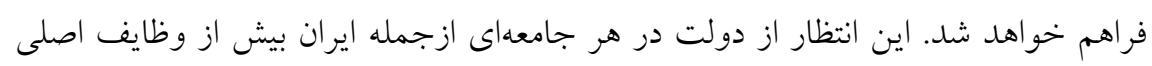

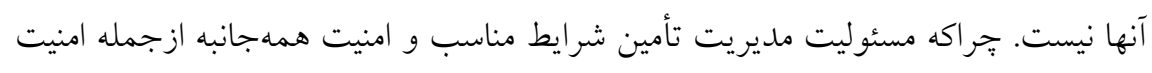

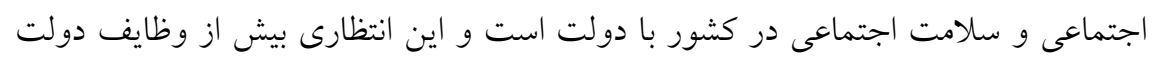

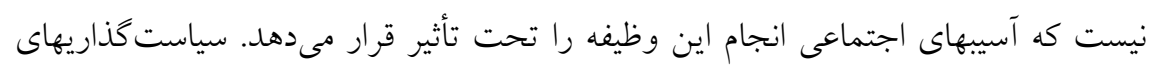

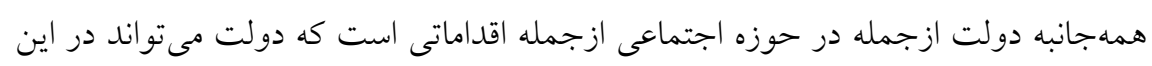

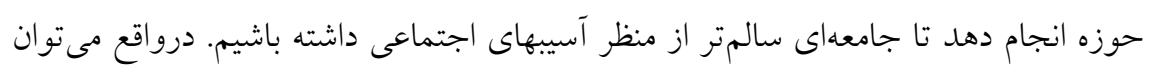

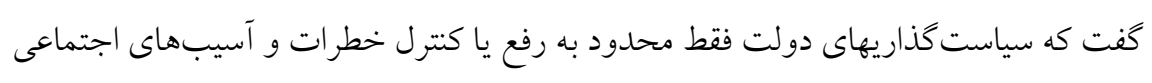

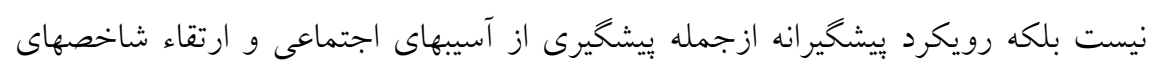

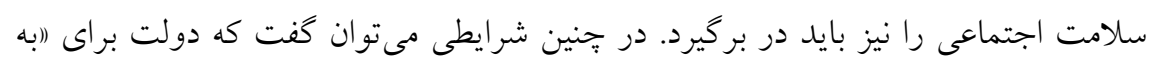


Social Welfare Quarterly, Vol 18, Fall 2018, No 70

زيستن اجتماعى" مردم نقشه راه مناسب دارد و سياست كذاريهاى مناسبى انجام داده است.

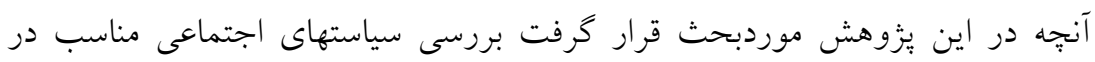

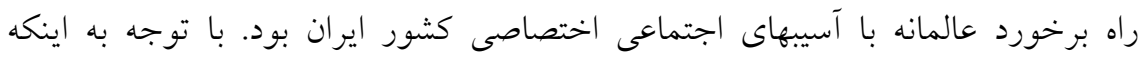

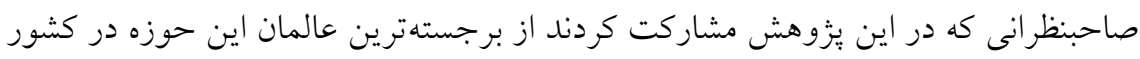

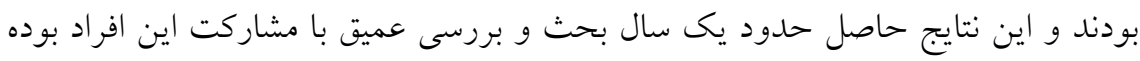

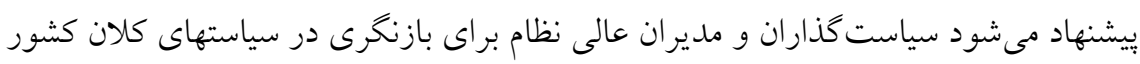

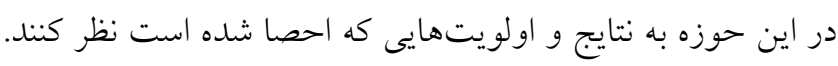

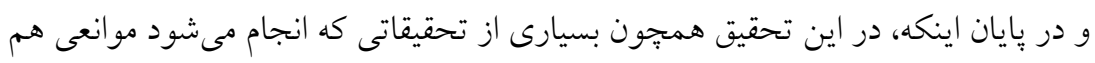

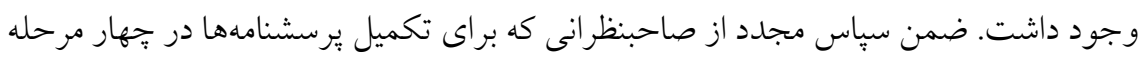
(ييشراند و سه راند) نهايت همكارى را داشتند و صاحبنظر انى كه در مصاحبه حضور داشتد ماند

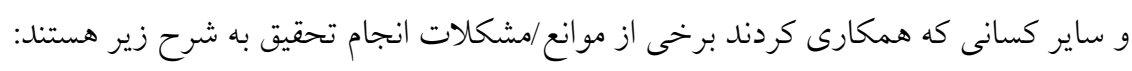

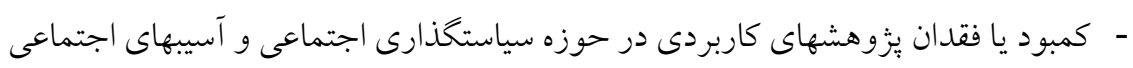

$$
\text { (يزوهشهاى مشابه) }
$$

- دسترسى كم به منابع غنى در ارتباط با موضوع سياستخذارى اجتماعى و آسيبهاى

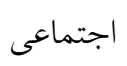

- تغيير جندباره در خصوص سؤ الات تحقيق توسط شوراى دانشگاه كه منجر به طولانى شدن انجام تحقيق شد. - طولانىبودن استفاده از روش دلفى براى جمع آورى اطلاعات كه مى تواند روى كيفيت ياسخها تأثير منفى داشته باشد. 
- Adams, R. (2002). Social Policy for Social Work (Vol. 1). London: Palgrave Macmillan.

- Arhami Dolatabadi, A., Kariman, H., Alimohammadi, H., Amini, A., \& Mousavifar, S. S. (2016). Trauma from Violence and Strife among Patients Referred to the Emergency Department; an Epidemiologic Study. 2016, 4(1), -4. doi: 10.22037/ijem.v4i1.13932 (in Persian)

- Baldock, J. (2014). Social policy, social welfare, and the welfare state. In J. Baldock, L. Mitton, N. Manning \& S. Vickerstaff (Eds.), Social policy (Vol. 1, pp. 5-30). Chicaco: Oxford University.

- Fischer, F., \& Miller, G. J. (2006). Handbook of public policy analysis: theory, politics, and methods: crc Press.

- Ghaffari, G., \& Azizimehr, K. (2012). Institutional approach and analysis of welfare policies in contemporary's Iran. Sociological Research, 19(1), 23-56. doi: 10.22059/jsr.2012.56172 (in Persian)

- Ghaffari, G., \& Habibpour Gottai, K. (2014). Social Policy the Conceptual and Theoretical Foundations. Tehran: Tehran University. (in Persian)

- Glicken, M. (2010). Social Work in the 21st Century: An Introduction to Social Welfare, Social Issues, and the Profession (Vol. 1). USA: SAGE Publications.

- Hartl, J. (1995). Social Policy: An Issue for Today and the Future Czech Sociological Review, 3 (2), 209-219

- Herrick, J. M. (2014). Social Policy: Overview: Oxford University Press.

- Khoshfar, G., Mohammadi, A., Mohammadzadeh, F., Mohammadi, R., \& Akbarzadeh, F. (2015). Social Security and Social Health (Case Study of 15-29 Years-Old Persons of Ghaen City). Iranian Journal of Social Research, 9(1), 71-102. (in Persian)

- Larson, J. S. (1993). The measurement of social well-being. Social Indicators Research, 28(3), 285-296.

- Naghibosadat, S. (2011). Methodology in Communication Science (Vol.

1). Tehran: Elm pub. (in Persian)

- Rafi'ey, H., Sami'ei, M., Foroozesh, K., Ghazarian, M., Rahimi, A., \& Akbarian, M. (2009). Combined Index of Social Health of Iran Journal of Social Security Research (Vol. 19, pp. 81-112). Tehran. (in Persian) - Safari, K., \& Shayeste, S. (2015). Study of Relationships Between Family Social Capital and Youth's Social Well-Being. Quarterly Journal of Social Work, 4(3), 5-17. (in Persian) 
- Samaram, E. (2008). Relationship Between Social Health and Social Security, with an Emphasis on the Approach of Social-Orieted Police. Journal of Social Security, 1(1), 21. (in Persian)

- Samaram, E. (2011). Social Health, the Core Theory of Social Work. Specialist Social Work, 1. (in Persian)

- Sami'ei, M., Rafi'ey, H., Amini Rarani , M., \& Akbarian, M. (2011). The Social Health of Iran: from a Consensus-Based Definition to an Evidence-Based Index. Social Problems of Iran, 1(8), 31-51. (in Persian)

- Saroukhani, B. (2004). Encyclopedia of Social Sciences (Vol. 2). Tehran: Etelaat pub (in Persian)

- Sedigh Sarvestani, R. (2017). Social Pathology: Sociology of Social Deviations. (in Persian)

- Vaez Mahdavi, Z., Vaez Mahdavi, M. R., \& Araei, M. M. (2013). The Impact of Social Policies on Human Development Following the 1979 Islamic Revolution in Iran (Vol. 2).

- Vesali, S., \& Omidi, R. (2014). Social policy: themes and approaches. The Journal of Planning and Budgeting, 19(1), 179-206. (in Persian)

- Yadav, A. K. (2015). Social Movements, Social Problems and Social Change. Academic Voices: A Multidisciplinary Journal, 5, 1-4. 